\title{
Gibberellin-responsive and -insensitive dwarfing alleles on wheat performance in contrasting tillage systems
}

Article

Accepted Version

Uppal, R.K. and Gooding, M.J. (2013) Gibberellin-responsive and -insensitive dwarfing alleles on wheat performance in contrasting tillage systems. Field Crops Research, 141. pp. 5562. ISSN 0378-4290 doi:

https://doi.org/10.1016/j.fcr.2012.11.001 Available at https://centaur.reading.ac.uk/29734/

It is advisable to refer to the publisher's version if you intend to cite from the work. See Guidance on citing.

To link to this article DOI: http://dx.doi.org/10.1016/j.fcr.2012.11.001

Publisher: Elsevier

All outputs in CentAUR are protected by Intellectual Property Rights law, including copyright law. Copyright and IPR is retained by the creators or other copyright holders. Terms and conditions for use of this material are defined in the End User Agreement.

www.reading.ac.uk/centaur 
Central Archive at the University of Reading

Reading's research outputs online 
1 Gibberellin-responsive and -insensitive dwarfing alleles on wheat

2 performance in contrasting tillage systems

3

$4 \quad$ R.K. Uppal, M.J. Gooding

5 School of Agriculture, Policy and Development, University of Reading, Earley Gate, P.O. Box

6 237, Reading, RG6 6AR, UK

7

8 ABSTRACT

9

10

Near-isogenic lines (NILs) of winter wheat varying for alleles for reduced height $(R h t)$, gibberellin $(\mathrm{GA})$ response and photoperiod insensitivity $(P p d-D 1 a)$ in cv. Mercia background (rht (tall), Rht-B1b, Rht-D1b, Rht-B1c, Rht8c+Ppd-D1a, Rht-D1c, Rht12) and cv. Maris Widgeon (rht (tall), Rht-D1b, Rht-B1c) backgrounds were compared to investigate main effects and interactions with tillage (plough-based, minimum-, and zero-tillage) over two years. Both minimum- and zero- tillage were associated with reduced grain yields allied to reduced harvest index, biomass accumulation, interception of photosynthetically active radiation (PAR), and plant populations. Grain yields were optimized at mature crop heights of around $740 \mathrm{~mm}$ because this provided the best compromise between harvest index which declined with height, and above ground biomass which increased with height. Improving biomass with height was due to improvements in both PAR interception and radiation-use efficiency. Optimum height for grain yield was unaffected by tillage system or GA-sensitivity. After accounting for effects of height, GA insensitivity was associated with increased grain yields due to increased grains per spike, which was more than enough to compensate for poorer plant establishment and lower mean grain weights compared to the GA-sensitive lines. 
25 Although better establishment was possible with GA-sensitive lines, there was no

26 evidence that this effect interacted with tillage method. We find, therefore, little

27 evidence to question the current adoption of wheats with reduced sensitivity to GA in

28 the UK, even as tillage intensity lessens.

29

30 Key words: zero tillage; minimum tillage; rht; gibberellin sensitivity; wheat

31 


\section{Introduction}

Wheat dwarfing alleles conferring insensitivity to gibberellic acid (GA), Rht-B1b and

$R h t-D 1 b$, have been widely adopted in wheat breeding programmes to reduce plant height and lodging, and increase harvest index and thereby grain yield (Chapman et al., 2007; Flintham et al., 1997; Addisu et al., 2010). These alleles, however, reduce coleoptile length and can also be associated with delayed emergence, smaller leaf areas, and slower accumulation of dry matter by seedlings (Botwright et al., 2001; Botwright et al., 2005; Rebetzke et al., 2001; Addisu et al., 2009). The negative effects on establishment and vigour are particularly pronounced when longer coleoptiles are required for seedlings to emerge from deep sowing to reach moist soil or when stubble load is high (Schillinger et al., 1998; Rebetzke et al., 2005).

A number of dwarfing alleles have been identified that retain response to endogenous gibberellin allowing selection for early vigour and coleoptile length (Rebetzke and Richards, 2000; Ellis et al., 2004). The GA sensitive semi-dwarfing allele, $R h t 8 c$ can confer grain yield and harvest indices similar to GA insensitive dwarfing alleles whilst retaining the coleoptile lengths and seedling vigor of taller lines (Rebetzke and Richards, 2000; Botwright et al., 2005; Addisu et al., 2009; 2010). Rht8c also has close linkage with a photoperiod-insensitive allele (Ppd-D1a) which reduces time to stem extension and flowering, and has also been associated with improved plant establishment rates in certain conditions (Addisu et al., 2010).

Reduced tillage systems have long been used to improve productivity and sustainability of cropping systems and to reduce the time and cost required for crop establishment (Trethowan et al., 2012). Despite the acknowledged benefits, reduced early growth is a common observation across soil types and environments (Kirkegaard et al., 1994; Weisz and Bowman, 1999). Crop yields are often lower under zero tillage 
during the initial years of transition from plough-based to reduced tillage systems due to increase in bulk density and soil strength, and reduced $\mathrm{N}$ availability (Ball et al., 1989; Christian and Ball, 1994; Kirkegaard et al., 1994; Alakukku et al., 2009; Kankanen et al., 2011). It is suggested, therefore, that breeding cultivars to exploit or tolerate the specific conditions that might occur in the initial years after adoption of reduced tillage systems could be fruitful (O’Leary \& Connor, 1997; Trethowan et al., 2012).

Experiments investigating tillage $\times$ genotype effects sometimes (Cox, 1991; Sip et al., 2009) but not always (Hall and Cholick, 1989; Trethowan et al., 2012) find significant interactions. There is little information on the benefits, or otherwise, of different dwarfing alleles for reduced tillage systems, although some QTLs identified of value for zero tillage at some field sites may co-locate with alleles for crop height and coleoptile length (Trethowan et al., 2012).

Here we investigate the tillage $\times$ GA response interaction using near-isogenic lines (NILs) in two wheat backgrounds (Mercia and Maris Widgeon) in an attempt to identify dwarfing alleles of particular worth to reduced tillage systems. We include three tillage systems; plough-based conventional- (CT); minimum- (MT); and zero- tillage (ZT) and a range of alleles that confer different effects on height with GA insensitivity $(R h t-B 1 b$, $R h t-D 1 b, R h t-B 1 c$ and $R h t-D 1 c)$ and GA sensitivity (rht(tall), Rht8c+Ppd-D1a and Rht12).

\section{Materials and Methods}

\subsection{Experimental site and crop husbandry}

A two-year field experiment (2009/10 and 2010/11) was conducted on a free draining sandy loam ( $9 \%$ (by volume) clay, particle size $<0.2 \mu \mathrm{m} ; 19 \%$ silt, $2-20 \mu \mathrm{m} ; 72 \%$ sand, 20-2000 $\mu \mathrm{m} ; \mathrm{pH}=6.6$ ) overlying coarse red-brown sand, of the Sonning series (Jarvis, 1968) at the Crops Research Unit, Sonning, The University of Reading, UK (51 
$29^{\prime} \mathrm{N}, 0^{\circ} 56^{\prime} \mathrm{W}, 35 \mathrm{~m}$ asl). The experiment followed a three year rye grass and chicory ley, destroyed by spraying $1.8 \mathrm{~kg} /$ ha glyphosate and then sub soiled to $400 \mathrm{~mm}$ at $1 \mathrm{~m}$ spacing. Weather data were recorded at an automated metrological station at the site (Table 1). Soil was tested for $\mathrm{pH}$, phosphorous, potassium and magnesium availability (Anon., 2000) and corrective nutrients applied as appropriate. Crop husbandry details are available in Table 2.

\subsection{Design of Experiment}

Tillage main plots $(50 \times 5 \mathrm{~m})$ were randomized in three blocks and divided into ten randomized sub-plots $(2.5 \times 10 \mathrm{~m})$ sown with different NILs at a rate of $300 \mathrm{seeds} / \mathrm{m}^{2}$. Conventional tillage main plots were ploughed to $300 \mathrm{~mm}$ and then power harrowed (Lely Roterra). For the minimum tillage plots there was no primary cultivation but a surface tilth $(20-30 \mathrm{~mm})$ was achieved with a single shallow pass with the power harrow (Baker et al., 1996).

Untreated seeds were drilled with a Hege 80 plot seed drill, mounted on a Hege 76 tool carrier in $120 \mathrm{~mm}$ rows in $1.9 \mathrm{~m} \times 10 \mathrm{~m}$ sub-plots, separated by $0.5 \mathrm{~m}$ double-width track wheelings, at a nominal depth of $50 \mathrm{~mm}$ for conventional, $30 \mathrm{~mm}$ in minimumtilled, and roughly into coulter slots in the zero-tilled treatments. The NILs were derived by backcrossing into the comparatively short (mean $820 \mathrm{~mm}$ at this site, Gooding et al., 2012) cv. Mercia (Talent/Virtue/Flanders, introduced in 1983) and the taller (1020mm) cv. Maris Widgeon (Holdfast/ Capelle Desprez, introduced in 1964). The Mercia NILs comprised: the parent line ( $r h t$, tall); gibberellin-insensitive semi-dwarf (Rht-B1b, Rht-D1b from 'Norin 10') and dwarf (Rht-B1c from 'Tom thumb'; Rht-D1c from 'Ai-Bian') lines; and gibberellin-sensitive semi-dwarf (Rht8c+Ppd-D1a from 'Mara') and dwarf (Rht12 from 'Karcagi 522') lines (Worland et al. 1994; Foulkes et al. 2004). The 
Maris Widgeon NILs comprised rht (tall), Rht-D1b, and Rht-B1c.

Before sowing the experiment a second time, for the 2010/11 growing season, weeds in stubbles of all plots were controlled by spraying $2.1 \mathrm{~kg} / \mathrm{ha}$ glyphosate. Tillage methods and NILs were superimposed on the same locations as used in the preceding year.

\subsection{Assessments}

Soil mineral N and total N, S and C were measured in December, February and October each year by taking five $72 \mathrm{~mm}$ diameter $\times 900 \mathrm{~mm}$ depth cores per main plot. Cores were separated into 0-300, 300-600 and 600-900 mm horizons. For total N, C and $\mathrm{S}$ samples were dried at $80^{\circ} \mathrm{C}$ for $48 \mathrm{~h}$. After grinding, 0.10 to $0.20 \mathrm{~g}$ samples were oxidatively combusted and assessed for elemental content with LECO FP-528 and a LECO SC-144DR (LECO Instruments, UK). For mineral N, soil was shaken with 2M KCl to extract the mineral-N fractions and a dry matter determination carried out. Then nitrate- $\mathrm{N}$ and ammonium- $\mathrm{N}$ were measured colourimetrically by determining the formation of a diazo compound between nitrite and sulphanilamide. This compound was then coupled with $\mathrm{N}$-1-Napthylethylenediamine dihydrochloride to give a red azo dye and then colour was measured at 540nm (Patton and Crouch, 1977). Results were reported as $\mathrm{mg} / \mathrm{l}$ in soil on a dry matter basis and then converted to kg mineral-N per hectare.

For bulk density five $72 \mathrm{~mm} \times 1000 \mathrm{~mm}$ cores were taken from each main plot and separated into $100 \mathrm{~mm}$ depth horizons. Samples were dried at $80^{\circ} \mathrm{C}$ for $48 \mathrm{~h}$ and weighed to derive bulk density as the mass of oven dried soil in a unit volume of the core.

Plant population was counted, and above ground crop biomass before the first node 
was detectable was hand-harvested, in three randomly-placed $0.1 \mathrm{~m}^{2}$ circular quadrats per sub-plot. At anthesis of the individual NILs (i.e. on different calendar days depending on NIL), the above ground crop was hand-harvested from rows both sides of a randomly-placed $0.5 \mathrm{~m}$ rule in three positions per sub-plot. The same sampling strategy was employed for hand-harvests at combine harvest maturity when samples were also portioned between grain and non-grain tissues to derive harvest index (HI). Above ground crop dry matter (AGDM) was determined after drying plants at $80^{\circ} \mathrm{C}$ for

48h. Crop height was calculated as the average of three assessments per sub-plot made between anthesis and harvest maturity with a rising disc of polystyrene (Peel, 1987). Interception of photosynthetically active radiation (PAR) was measured above and below (10mm above soil level) the canopy at three locations per subplot with a dual sensor ceptometer (AccuPAR LP-80 Decagon Devices Inc, Pullman, Washington) at approximately 14-day intervals from seedling emergence until interception started to decline with crop senescence. A logistic curve was fitted to the \% interception $\mathrm{x}$ time curve for each plot to provide fitted daily estimates of \% interception. These estimates were multiplied by the daily radiation recorded at an automatic weather station adjacent to the experiments. The products were summed to estimate the total radiation intercepted by each plot during the period of assessment.

The central $1.3 \mathrm{~m}$ of each sub-plot was combine harvested for grain yield assessment. Grain moisture content was determined by drying a 20 g sample at $80^{\circ} \mathrm{C}$ for $48 \mathrm{~h}$ allowing adjustment to dry matter basis. Mean grain weight was assessed by weighing a 250 grain lot after dividing the sup-plot samples.

\subsection{Statistical Analysis}

Statistical analysis was with routines in GENSTAT 11 . The analyses of variance 
(ANOVA) comprised a block structure of Block / Tillage / Line / Year, i.e. as plots of the same treatment were superimposed on each other in the successive years Year was treated as a further split to the Line sub-plots within the Tillage main-plots. The treatment structure was Tillage * Line * Year. For the soil tests, there was insufficient precision when tillage treatments were included as individual levels. This weakness was partially rectified by contrasting With Inversion (CT) against Without Inversion (MT+ZT). To further test effects and interactions of GA-sensitivity, whilst also accounting for linear and quadratic effects of height, an analysis of Residual Maximum Likelihood (REML) was conducted where the fixed effects were Year *Tillage *(Height + Height $\left.^{2}\right) *$ GA sensitivity, and the random model was as for the ANOVA block structure. For presentation purposes the main effects of background (Mercia or Maris Widgeon) on the quadratic responses of variates to height have been removed by subtracting the background effects on the regression constant to rebase the constant to that of Mercia.

\section{Results}

The 2009/10 season was exceptionally wet in winter and then drier from stem elongation to the end of grain filling (April to July) (Table 1). In 2010/11 there was a particularly dry spring extending from stem elongation to ear emergence (March to May).

\subsection{Effect of tillage on soil properties}

For the 2009/10 growing season total N, C, S and ammonium N at the time of sowing were not significantly affected by tillage system (Table 3). Total $\mathrm{N}$ was, however, significantly higher following conventional tillage because of the increase in nitrate N. In 
February, all soil nutrients were similar in all tillage systems except that nitrate $\mathrm{N}$ was still lower in the reduced tillage systems. After harvest, total N was significantly higher in conventional tillage whereas other soil parameters did not differ among tillage systems.

For the 2010/11 growing season in February, total N and nitrate N were significantly higher in conventional tillage. After harvest, total N, C and S were not affected by tillage system.

Bulk density for the 0-300mm horizon was significantly higher in MT and ZT compared to CT in both seasons (Table 4). In 2010, soil bulk density was significantly higher in MT in the 300-600mm horizon whereas at the same depth in 2011, it was significantly higher in CT.

\subsection{Crop Performance}

\subsubsection{Effects of height}

Grain yields were optimized at heights around 740mm (Fig. 1a,b) because this provided the best compromise between harvest index, which declined with height (Fig. 1c,d), and above ground biomass which increased with height (Fig. 2c,e). Improving AGDM with height was due to improvements in both PAR interception (Fig. 2g) and RUE (Fig. 2i). The quadratic grain yield response to height was mostly the result of effects on grains per spike (Fig. 3e), and hence also grains per unit area (Fig. 3c), rather than on mean grain weight which increased with height (Fig. 3a). There appeared no response to height for plant establishment (Fig. 3i), early biomass production (Fig. 2a) nor ears per plant (Fig. 3g).

\subsubsection{Effects of GA response}


After accounting for effects of height, GA insensitivity was associated with increased grain yields (Fig. 1a). This derived from increased grains per spike and per unit area (Fig. 3c,e), which was more than enough to compensate for poorer plant establishment (Fig. 3i) and lower mean grain weights (Fig. 3a) compared to the GA-sensitive lines. GAinsensitivity had little effect on AGDM at harvest (Fig. 2e) because benefits for PAR interception were countered by reduced RUE. Despite effects on plant establishment, there appeared little effect of GA-response on early biomass production (Fig. 2a), ears per plant (Fig. 3g) or harvest index (Fig. 1c).

\subsubsection{Effects of tillage}

Both minimum- and zero- tillage were associated with reduced grain yields (Fig. 1b), allied to reduced harvest index (Fig. 1d) and biomass accumulation (Fig. 2b,d,f). Reduced biomass accumulation was due to lower amounts of PAR intercepted (Fig. 2h) rather than effects on RUE (Fig. 2j). Poorer PAR interception resulted from the smaller plant populations in the reduced-tillage systems (Fig. 3j). Although there was some compensation for lower plant numbers with increased ears per plant, particularly for ZT (Fig. 3h), this was insufficient to maintain grain numbers per unit area the level achieved in the plough-based system (Fig. 3d). There was no effect of tillage on grains per spike (Fig. 3f), or mean grain weight (Fig. 3b). There was no evidence of an interaction between tillage and GA response for any of the variates measured. There was an interaction between line and tillage for plant establishment (Fig. 3j) and also for AGDM at anthesis (Fig. 2d). With regards establishment there appeared some advantage for dwarfism in the ZT, although the opposite occurred under CT (Fig 3j). At anthesis there was no benefit of height for AGDM after ZT but there was an increase in AGDM with stature following both MT and ZT. 


\section{Discussion}

\subsection{Effect of tillage systems}

The increased bulk density and lower concentrations of mineral $\mathrm{N}$ (principally nitrate) in the early years of adoption of reduced tillage systems is consistent with previous reports (Baumer and Kopke., 1989; Riley et al., 1994; Munkholm et al., 2003). These effects of reduced tillage may have contributed to poor plant establishment and early growth, but other explanations such as poor seed burial and associated exposure and predation, or increased disease pressures from surface trash are also potential additional causes (Davies and Finney, 2002; Siemens et al., 2004; Mikkola et al., 2005). Although poor establishment in the reduced tillage systems was partly countered by increased numbers of ears per plant, this was far from fully-compensatory with regards to PAR interception and hence biomass accumulation and yield. Kirkgaard et al. (1994) noted that while reduced early growth is a consistent effect of direct drilling or stubble retention, subsequent growth and yield will depend on seasonal conditions. In more humid conditions at this site (Gooding et al., 2002) it is possible for yields not to be constrained by plant populations similar to those achieved here by MT. However, the dry springs recorded in the present experiments, particulary as they were coincident with poor uptake of large nitrogen top-dressings (Uppal, 2012), can be considered to have significantly limited the ability of the wheat to compensate for poor establishment after reduced tillage in these seasons. The reason why reduced tillage led to poorer harvest indices is less clear. It is possible that the sparse populations led to an increase in late, non-fertile tillers (Gooding et al., 2002). 

mean grain weight up to heights of around 1m; and declines in harvest index, grains per spike and hence also grain yield as heights exceed about $800 \mathrm{~mm}$ is consistent with previous experiments with these alleles at this site and elsewhere in the UK (Flintham et al., 1997 Addisu et al., 2010; Gooding et al., 2012). Except for plants per unit area, we find no evidence that tillage system alters the optimum height for grain yield and its components when stature is modified by major dwarfing alleles. The interaction between tillage system and a crop's ultimate height for plant establishment has not been reported previously. We confirm the penalty for severe dwarfism on plant establishment after plough-based tillage (Addisu et al. 2009), but also find this effect to disappear or reverse in the more challenging conditions of our MT and ZT systems. The basis for this interaction is unclear. It is possible that sowing depth is important, i.e. coleoptile length and seedling vigour were possibly less important in the shallower drilling for the reduced tillage systems.

\subsection{Effects of GA response}

We confirm that GA insensitivity can be detrimental to crop establishment (Rebetzke et al. 2001; Addisu et al. 2009). In other studies this negative effect has been particularly evident in challenging conditions for establishment e.g.: when longer coleoptiles were required for deeper planting (Schillinger et al., 1998; Botwright et al., 2001; Rebetzke et al., 2007); when stubble load was large (Rebetzke et al., 2005); or when excessively warm seed beds compromised emergence (Bai et al., 2004). In contrast, although our reduced tillage systems did challenge establishment, as evidenced by substantially reduced plant numbers in MT and ZT, we found no GA sensitivity x tillage interaction. It

277 is possible that GA sensitivity is particularly beneficial for deep sowing and this was not a factor in our reduced tillage systems. Similarly, it might be supposed that the benefit 
for GA sensitivity on plant establishment would have been more likely to lead to higher grain yields in a spring-sown crop (as in Rebetzke et al. 2007) where there was less time for compensatory ear production from GA-insensitive lines.

We confirm that dwarfing with GA-insensitivity can increase grain numbers per spike and reduce mean grain weight (Fintham et al., 1997). What is more notable here, however, is that these effects persist even when the influence of height has been accounted for, i.e. it appears that there are beneficial effects of GA-insensitivity on grain numbers per spike that are not due to effects on ultimate height per se. This is somewhat at variance with the interpretation of Flintham et al. (1997) who argued that GA insensitivity from major Rht alleles was limited to below the collar node. Hence, effects on grain numbers (specifically, increased fertility of distal florets within spikelets) were purely a response to assimilate source : sink relations. Before rejecting this argument, however, some caution is required. In our experiments one of the GAsensitive lines (Mercia Rht8c) is combined with Ppd-D1a, and Maris Widgeon rht (tall) could not be compared with a GA-insensitive line of comparable height.

In conclusion, we find no evidence that the optimal ultimate crop height, as modified by major dwarfing alleles, varies with the tillage systems used here. Although GA-insensitive alleles were associated with poorer establishment, and lower yields in the reduced tillage systems were linked to reduced plant populations, benefits of GAsensitivity did not interact with establishment method and were insufficient to compensate for fewer grains per spike. We find, therefore, little evidence to question the current adoption of wheats with reduced sensitivity to GA in the UK, even as tillage intensity lessens. 


\section{Acknowledgements}

The authors are grateful to Mr Richard Casebow for technical assistance and Professor John Snape, John Innes Centre for supply of the near-isogenic lines.

\section{References}

Addisu, M., Snape, J.W., Simmonds, J.R., Gooding, M.J., 2009. Reduced height (Rht) and photoperiod insensitivity $(P p d)$ allele associations with establishment and early growth of wheat in contrasting production systems. Euphytica 166, 249-263.

Addisu, M., Snape, J.W., Simmonds, J.R., Gooding, M.J., 2010. Effects of reduced height (Rht) and photoperiod insensitivity $(P p d)$ alleles on yield of wheat in contrasting production systems. Euphytica 172, 169-181.

Alakukku, L., Ristolainen, A., Salo, T., 2009. Grain yield and nutrient balance of spring cereals in different tillage systems. In: Sustainable Agriculture; Proceedings of ISTRO $18^{\text {th }}$ triennial conference, Izmir, Turkey.

Anon., 2000. Fertiliser recommendations for agricultural and horticultural crops. MAFF reference book 209, 7th edn. HMSO, London

Bai, G.H., Das, M.K., Carver, B.F., Xu, X.Y., Krenzer, E.G., 2004. Covariation for microsatellite marker alleles associated with Rht8 and coleoptile length in winter wheat. Crop Sci. 44, 1187-1194.

Ball, B.C., Lang, R.W., O’Sullivan, M.F., Franklin, M.F., 1989. Cultivation and nitrogen requirements for continuous winter barley on a geysol and a cambisol. Soil Till. Res. $13,333-352$.

Baker, C.J., Saxton, K.E., Ritchie, W. R. 1996. No-tillage Seeding : Science and Practice. CAB International, Wallingford, $258 \mathrm{pp}$. 
Baumer, K., Kopke, U., 1989. Effects of nitrogen fertilization. In: Baumer, K., Ehlers, W. (Eds.), Agriculture. Energy Saving by Reduced Soil Tillage. Commission of the European Communities, Report EUR 11258, pp. 145-162.

Botwright, T., Rebetzke, G.J., Condon, A.G., Richards, R.A., 2001. The effect of rht genotype and temperature on coleoptile growth and dry matter partitioning in young wheat seedlings. Austral. J. Plant Physiol. 28, 417-423.

Botwright, T., Rebetzke, G.J., Condon, A.G., Richards, R.A., 2005. Influence of gibberellinsensitive Rht8 dwarfing gene on leaf epidermal cell dimensions and early vigour in wheat (Triticum aestivum L.). Ann. Bot. 95, 631-639.

Chapman, S.C., Mathews, K.L., Trethowan, R.M., Singh, R.P., 2007. Relationships between height and yield in near-isogenic spring wheats that contrast for major reduced height genes. Euphytica 157, 391-397.

Christian, D.G., Ball, B.C., 1994. Reduced cultivation and direct drilling for cereals in Great Britain. In: Carter, M.R. (Ed.), Conservation tillage in Temperate Agroecosystems. Lweis Publ., Boca Raton, FL., USA, pp. 117-140.

Cox, D.J., 1991. Performance of hard red winter wheat cultivars under conventional-till and no-till systems. North Dakota Farm Research 48, 17-20.

Davies, B., Finney, B., 2002. Reduced Cultivations for Cereals: Research Development and Advisory Needs under Changing Economic Circumstances. Home Grown Cereals Authority, London (Research Review No. 48)

Ellis, M.H., Rebetzke, G.J., Cahndler, P., Bonnett, D., Spielmeyer, W., Richards, R.A., 2004. The effect of different height reducing genes on the early growth of wheat. Funct. Plant Biol. 31, 583-589.

Flintham, J.E., Borner, A.B., Worland, A.J., Gale, M.D., 1997. Optimizing wheat grain yield : effects of $R h t$ (gibberellin-insensitive) dwarfing genes. J. Agric. Sci. 128, 11-25. 
Foulkes, M.J., Sylvester-Bradley, R., Worland, A.J., Snape, J.W., 2004. Effects of a photoperiod-response gene Ppd-D1 on yield potential and drought resistance in UK winter wheat. Euphytica 135, 63-73.

Gooding, M.J., Pinyosinwat, A., Ellis, R.H., 2002. Responses of wheat grain yield and quality to seed rate. J. Agric. Sci. 138, 317-331.

Gooding, M.J., Addisu, M., Uppal, R.K., Snape, J.W., Jones, H.E., 2012. Effect of wheat dwarfing genes on nitrogen use efficiency. J. Agric. Sci. 150, 3-22.

Hall, E.F., Cholick, F.A., 1989. Cultivar $\times$ tillage interaction of hard red spring wheat cultivars. Agron. J. 81, 789-792.

Jarvis, R.A., 1968. Soils of the Reading District. Rothamsted Experimental Station, Harpenden, UK.

Kankanen, H., Alakukku, L., Salo, Y., Pitkanen, T., 2011. Growth and yield of different spring cereal species in zero tillage, compared to conventional tillage. Eur. J. Agron. 34, 3545.

Kirkegaard, J.A., Angus, J.F., Gardner, P.A., Miiller, W., 1994. Reduced growth and yield of wheat with conservation cropping. I. Field studies in the first year of the cropping phase. Austral. J. Agric. Res. 45, 511-528.

Mikkola, H.J., Alakukku, L., Kankanen, H., Jalli, H., Lindroos, M., Huusela-Veistola, E., Nuutinen, V., Latti, M., Puustinen, M., Turtola., E., Myllys, M., Regina, K., 2005. Direct drilling in Finland, a review. In: Proc. $4^{\text {th }}$ Intern. Scientific and Practical Conference, Ecology and Agricultural Machinery, May 25-26, 2005, St Petersburg, Vol. 2, pp, 141151

Munkholm, L.J., Schjonning, P., Rasmussen, K.J., Tanderup, K. 2003. Spatial and temporal effects of direct drilling on soil structure in the seeding environment. Soil tillage Res. 71, 163-173. 
O'Leary, G.J., Connor, D.J., 1997. Stubble retention and tillage in a semi-arid environment: 3. Response of wheat. Field Crop Res. 54, 39-50.

Patton, C.J., Crouch, S.R., 1977. Spectrophotometric and kinetics investigation of berthelot reaction for determination of ammonia. Anal. Chem. 49, 464-469.

Peel, C.H., 1987. Technical note. A rising disc apparatus for the measurement of turfgrass sward heights. J. Sports Turf Res. Inst. 63, 116-135.

Rebetzke, G.J., Richards, R.A., 2000. Gibberellic acid-sensitive dwarfing genes reduce plant height to increase seed number and grain yield of wheat. Austral. J. Agric. Res. 51, $235-245$.

Rebetzke, G.J., Appels, R., Morrison, A.D., Richards, R.A., McDonald, G., Ellis, M.H., Spielmeyer, W., Bonneti, D.G., 2001. Quantitative trait loci on chromosome 4B for coleoptile length and early vigour in wheat (Triticum aestivum L.). Austral. J. Agric. Res. 52, 1221-1234.

Rebetzke, G.J., Bruce, S.E., Kirkegaard, J.A., 2005. Longer coleoptiles improve emergence through crop residues to increase seedling number and biomass in wheat (Triticum aestivum L.). Plant Soil 272, 87-100.

Rebetzke, G.J., Ellis, M.H., Bonnett, D.G., Richards, R.A., 2007. Molecular mapping of genes for coleoptile growth in bread wheat (Triticum aestivum L.). Theor. Appl. Genet. 114, 1173-1183.

Riley, H., Borrenson, T., Ekeberg, E., Rydberg, T. 1994. Trends in reduced tillage research and practice in Scandinavia. In: Carter, M.R. (Eds.) Conservation Tillage in Temperate Agroecostystems. Lewis Publishers, Boca Raton, Florida, USA, pp, 23-45.

Schillinger, W.F., Donaldson, E., Allan, R.E., Jones, S.S., 1998. Winter wheat seedling emergence from deep sowing depths. Agron. J. 90, 582-586.

Siemens, M.C., Wilkins, D.E., Correa, R.F. 2004. Development and evaluation of a residue 

management wheel for hoe-type no-till drills. Trans of Am Soc Agric Eng. 47, 397-404.

404

405

406

407

408

409

410

411

412

413

414

415

416

417

Sip, V., Ruzek, P., Chrpova, J., Vavera, R., Kusa, H., 2009. The effect of tillage practice, input level and environment on the grain yield of winter wheat in the Czech Republic. Field Crop Res. 113, 131-137.

Trethowan, R.M., Mahmood, T., Ali, Z., Oidach, K., Garcia, A.G., 2012. Breeding wheat cultivars better adapted to conservation agriculture. Field Crop. Res. 132, 76-83.

Uppal, R. 2012. Effect of wheat dwarfing alleles on physiology of yield and nitrogen use efficiency in contrasting tillage systems. PhD Thesis, University of Reading

Weisz, R., Bowman, D.T., 1999. Influence of tillage system on soft red winter wheat cultivar selection. J. Production Agric. 12, 415-418.

Worland, A.J., Sayers, E.J., Borner, A., 1994. The genetics and breeding potential of Rht12, a dominant dwarfing gene in wheat. Plant Breed. 113, 187-196.

Zadoks, J.C., Chang, T.T., Konzak, C.F., 1974. A decimal code for the growth stages of cereals. Weed Res. 44, 415-421. 
Fig. 1. Effect of final crop height, gibberellin (GA) sensitivity and tillage on the grain yield and harvest index of near-isogenic wheat lines varying for reduced height alleles. Panels on left compare GA-insensitive ( $\bullet$, solid line) and sensitive ( $\circ$, dashed line) alleles averaged over tillage and year. Numerals 0, 1, 2, 3, 8, 10 and 12 in panel $a$ correspond to rht(tall), Rht-B1b, Rht-D1b, Rht-B1c, Rht8c +Ppd-D1a, Rht-D1c, and Rht12 respectively; M=Mercia; W=Maris Widgeon. Alleles in other panels can be deduced as heights are the same. Panels on right compare lines in different tillage treatments (plough-based $=\mathbf{\square}$, solid line; minimum tillage $=\square$, dashed line; zero-tillage $=+$, dotted line), averaged over year, where only GA-sensitive alleles are labelled. Error bars are single standard error of difference (SED) for comparing lines (within Tillage on right); error degrees of freedom $=54$. Effects of background ( $\mathrm{M}$ or $\mathrm{W}$ ) have been removed (see text for details); main and interacting effects of GA-sensitivity, Tillage, Linear Height and Quadratic Height only fitted if effect is statistically significant $(P<0.05)$.

Fig. 2. Effect of final crop height, gibberellin (GA) sensitivity and tillage on the accumulation of above ground biomass, interception of photosynthetically active radiation (PAR), and radiation use efficiency (RUE) of near-isogenic wheat lines varying for reduced height alleles. Panels on left compare GA-insensitive $(\bullet$, solid line) and sensitive $(\circ$, dashed line) alleles averaged over tillage and year. Numerals 0, 1, 2, 3, 8, 10 and 12 in panel $a$ correspond to rht(tall), Rht-B1b, Rht-D1b, Rht-B1c, Rht8c+Ppd-D1a, Rht-D1c, and Rht12 respectively; M=Mercia; W=Maris Widgeon. Alleles in other panels can be deduced as heights are the same. Panels on right compare lines in different tillage treatments (plough-based $=\mathbf{\square}$, solid line; minimum tillage $=\square$, dashed line; zero-tillage $=+$, dotted line), averaged over year, where only GA-sensitive alleles are labelled. Error bars are single standard error of difference (SED) for comparing lines (within Tillage on right); error degrees of freedom $=54$. Effects of background (M or W) have been removed (see text for details); main and interacting effects 

significant $(\mathrm{P}<0.05)$.

448 Fig. 3. Effect of final crop height, gibberellin (GA) sensitivity and tillage on the yield components of 449 near-isogenic wheat lines varying for reduced height alleles. Panels on left compare GA-insensitive $450(\bullet$, solid line) and sensitive ( $($, dashed line) alleles averaged over tillage and year. Numerals $0,1,2,3$, 8, 10 and 12 in panel $a$ correspond to rht(tall), Rht-B1b, Rht-D1b, Rht-B1c, Rht8c+Ppd-D1a, RhtD1c, and Rht12 respectively; $\mathrm{M}=$ Mercia; $\mathrm{W}=$ Maris Widgeon. Alleles in other panels can be deduced as heights are the same. Panels on right compare lines in different tillage treatments (plough-based =

454 口, solid line; minimum tillage $=\square$, dashed line; zero-tillage $=+$, dotted line), averaged over year, 455 where only GA-sensitive alleles are labelled. Error bars are single standard error of difference (SED) 456 for comparing lines (within Tillage on right); error degrees of freedom = 54. Effects of background 457 ( $\mathrm{M}$ or $\mathrm{W}$ ) have been removed (see text for details); main and interacting effects of GA-sensitivity, 458 Tillage, Linear height and Quadratic height only fitted if effect is statistically significant $(P<0.05)$. 459 
Table 1

2 Monthly weather data during crop growing seasons and mean (41 years for temperature and 51 years for 3 rainfall) at the Crop Research Unit, Sonning, The University of Reading, UK.

\begin{tabular}{|c|c|c|c|c|c|c|}
\hline & \multicolumn{3}{|c|}{ Temperature $\left({ }^{\circ} \mathrm{C}\right)$} & \multicolumn{3}{|c|}{ Rainfall (mm) } \\
\hline & $2009 / 10$ & $2010 / 11$ & Mean & $2009 / 10$ & $2010 / 11$ & Mean \\
\hline Sep & 14.4 & 13.5 & 14.2 & 17.0 & 48.4 & 55.0 \\
\hline Oct & 9.7 & 10.4 & 10.8 & 43.4 & 60.4 & 66.1 \\
\hline Nov & 10.8 & 5.4 & 7.1 & 145.3 & 39.8 & 65.4 \\
\hline Dec & 2.9 & 0.2 & 4.9 & 104.4 & 23.4 & 62.9 \\
\hline Jan & 1.4 & 3.9 & 4.4 & 67.6 & 83.6 & 59.2 \\
\hline Feb & 3.6 & 6.5 & 4.5 & 61.0 & 51.2 & 41.4 \\
\hline Mar & 6.3 & 6.5 & 6.5 & 46.2 & 13.8 & 48.2 \\
\hline Apr & 9.2 & 12.2 & 8.7 & 22.0 & 2.8 & 47.4 \\
\hline May & 11.2 & 12.3 & 12.1 & 12.0 & 30.0 & 49.3 \\
\hline Jun & 16.1 & 14.2 & 15.1 & 20.8 & 89.8 & 47.9 \\
\hline Jul & 18.4 & 15.7 & 17.3 & 31.6 & 40.0 & 47.4 \\
\hline Aug & 16.1 & 15.9 & 16.9 & 108.0 & 125.2 & 57.3 \\
\hline
\end{tabular}

4 
Table 2

6 Husbandry applied during the two growing seasons of the experiment

\begin{tabular}{|c|c|c|c|}
\hline Treatment & $\begin{array}{l}\text { Growth } \\
\text { Stage } \\
\text { (Zadoks et } \\
\text { al., 1974) }\end{array}$ & $2009 / 10$ & $2010 / 11$ \\
\hline Herbicide & Pre-drilling & Glyphosate $1.8 \mathrm{~kg} / \mathrm{ha}$ (twice) & Glyphosate $2.1 \mathrm{~kg} / \mathrm{ha}$ \\
\hline Fertilizer & Pre-drilling & $120 \mathrm{Kg} \mathrm{K}_{2} \mathrm{O} / \mathrm{ha}$ & - \\
\hline Herbicide & Pre-drilling & Glyphosate $1.4 \mathrm{~kg} / \mathrm{ha}$ & Glyphosate $0.5 \mathrm{~kg} / \mathrm{ha}$ \\
\hline Drilling & & 06.11 .2009 & 10.11 .2010 \\
\hline Fertilizer & $30-31$ & $100 \mathrm{~kg} \mathrm{~N} / \mathrm{ha}+40 \mathrm{~kg} \mathrm{~S} / \mathrm{ha}$ & $100 \mathrm{~kg} \mathrm{~N} / \mathrm{ha}+40 \mathrm{~kg} \mathrm{~S} / \mathrm{ha}$ \\
\hline Fungicide & $30-31$ & $\begin{array}{l}\text { Epoxiconazole } 125 \mathrm{~g} / \mathrm{ha}+ \\
\text { Quinoxyfen } 150 \mathrm{~g} / \mathrm{ha}+ \\
\text { Chlorothalonil } 1 \mathrm{~kg} / \mathrm{ha}\end{array}$ & $\begin{array}{l}\text { Epoxiconazole } 125 \mathrm{~g} / \mathrm{ha}+ \\
\text { Chlorothalonil } 1 \mathrm{Kg} / \mathrm{ha}+ \\
\text { Metrafenon } 150 \mathrm{~g} / \mathrm{ha}\end{array}$ \\
\hline Herbicide & $31-32$ & $\begin{array}{l}\text { Metsulfuron methyl } 5 \mathrm{~g} / \mathrm{ha}+ \\
\text { Thifensulfuron methyl } \\
50 \mathrm{~g} / \mathrm{ha}\end{array}$ & $\begin{array}{l}\text { Metsulfuron methyl } 5 \mathrm{~g} / \mathrm{ha}+ \\
\text { Thifensulfuron methyl } 50 \mathrm{~g} / \mathrm{ha}\end{array}$ \\
\hline Fertilizer & $34-39$ & $100 \mathrm{~kg} \mathrm{~N} / \mathrm{ha}$ & $100 \mathrm{~kg} \mathrm{~N} / \mathrm{ha}$ \\
\hline Fungicide & 39 & $\begin{array}{l}\text { Epoxiconazole } 125 \mathrm{~g} / \mathrm{ha}+ \\
\text { Azoxystrobin } 250 \mathrm{~g} / \mathrm{ha}\end{array}$ & $\begin{array}{l}\text { Epoxiconazole } 125 \mathrm{~g} / \mathrm{ha}+ \\
\text { Azoxystrobin } 250 \mathrm{~g} / \mathrm{ha}\end{array}$ \\
\hline Fungicide & 59 & $\begin{array}{l}\text { Tebuconazole } 250 \mathrm{~g} / \mathrm{ha}+ \\
\text { Deltamethrin } 5 \mathrm{~g} / \mathrm{ha}\end{array}$ & Tebuconazole $250 \mathrm{~g} / \mathrm{ha}$ \\
\hline Herbicide & Pre-harvest & - & Glyphosate $1.4 \mathrm{~kg} / \mathrm{ha}$ \\
\hline Harvested & & 16.08 .2010 & 22.08 .2011 \\
\hline
\end{tabular}

7 
Table 3

10 Effect of different tillage systems on soil nutrients

\begin{tabular}{|c|c|c|c|c|c|c|}
\hline & $\begin{array}{c}\text { Total N } \\
\text { (mg/kg) }\end{array}$ & $\begin{array}{l}\text { Total C } \\
\text { (mg/kg) }\end{array}$ & $\begin{array}{c}\text { Total S } \\
\text { (mg/kg) }\end{array}$ & $\begin{array}{c}\text { Available N } \\
\text { (kg/ha) }\end{array}$ & $\begin{array}{l}\text { Ammonium } \\
\mathrm{N}(\mathrm{mg} / \mathrm{kg})\end{array}$ & $\begin{array}{r}\text { Nitrate N } \\
(\mathrm{mg} / \mathrm{kg})\end{array}$ \\
\hline \multicolumn{7}{|l|}{ November 2009} \\
\hline Zero + Min- tillage & 0.58 & 7.88 & 0.16 & 34.6 & 0.58 & 2.3 \\
\hline Conventional tillage & 0.75 & 6.45 & 0.12 & 49.3 & 0.61 & 3.5 \\
\hline$P$ & 0.083 & 0.203 & 0.379 & 0.047 & 0.389 & 0.050 \\
\hline SED & 0.078 & 0.974 & 0.047 & 5.62 & 0.034 & 0.47 \\
\hline \multicolumn{7}{|l|}{ February 2010} \\
\hline Zero + Min- tillage & 0.68 & 8.53 & 0.14 & 32.5 & 1.94 & 0.78 \\
\hline Conventional tillage & 0.70 & 8.34 & 0.17 & 33.8 & 1.55 & 1.26 \\
\hline$P$ & 0.146 & 0.876 & 0.263 & 0.818 & 0.369 & 0.064 \\
\hline SED & 0.013 & 1.133 & 0.021 & 5.37 & 0.389 & 0.206 \\
\hline \multicolumn{7}{|l|}{ October 2010} \\
\hline Zero + Min- tillage & 0.88 & 7.10 & 0.12 & 57.3 & 0.49 & 4.29 \\
\hline Conventional tillage & 0.94 & 7.37 & 0.11 & 61.2 & 0.56 & 4.54 \\
\hline$P$ & $<0.001$ & 0.637 & 0.680 & 0.415 & 0.489 & 0.546 \\
\hline SED & 0.004 & 0.531 & 0.007 & 4.4 & 0.098 & 0.394 \\
\hline \multicolumn{7}{|l|}{ February 2011} \\
\hline Zero + Min- tillage & 0.96 & 7.09 & 0.14 & 28.3 & 0.85 & 1.52 \\
\hline Conventional tillage & 1.08 & 7.41 & 0.13 & 36.8 & 0.84 & 2.22 \\
\hline$P$ & 0.025 & 0.693 & 0.695 & 0.102 & 0.886 & 0.065 \\
\hline SED & 0.039 & 0.767 & 0.025 & 4.19 & 0.067 & 0.30 \\
\hline \multicolumn{7}{|l|}{ October 2011} \\
\hline Zero + Min- tillage & 0.85 & 7.07 & 0.011 & & & \\
\hline Conventional tillage & 0.85 & 6.70 & 0.012 & & & \\
\hline$P$ & 0.932 & 0.563 & 0.526 & & & \\
\hline SED & 0.027 & 0.602 & 0.020 & & & \\
\hline
\end{tabular}


12 Table 4

13 Effect of different tillage systems on soil bulk density in two soil horizons

\begin{tabular}{|c|c|c|c|c|}
\hline \multirow{2}{*}{$\begin{array}{l}\text { Tillage } \\
\text { Depth (mm) }\end{array}$} & \multicolumn{2}{|c|}{2010} & \multicolumn{2}{|c|}{2011} \\
\hline & $0-300$ & $300-600$ & $0-300$ & $300-600$ \\
\hline Plough-based & 1.49 & 1.60 & 1.49 & 1.73 \\
\hline Minimum & 1.57 & 1.65 & 1.58 & 1.65 \\
\hline Zero & 1.58 & 1.61 & 1.60 & 1.67 \\
\hline$P$ & 0.006 & 0.027 & 0.002 & 0.045 \\
\hline SED & 0.014 & 0.011 & 0.012 & 0.022 \\
\hline
\end{tabular}

14 


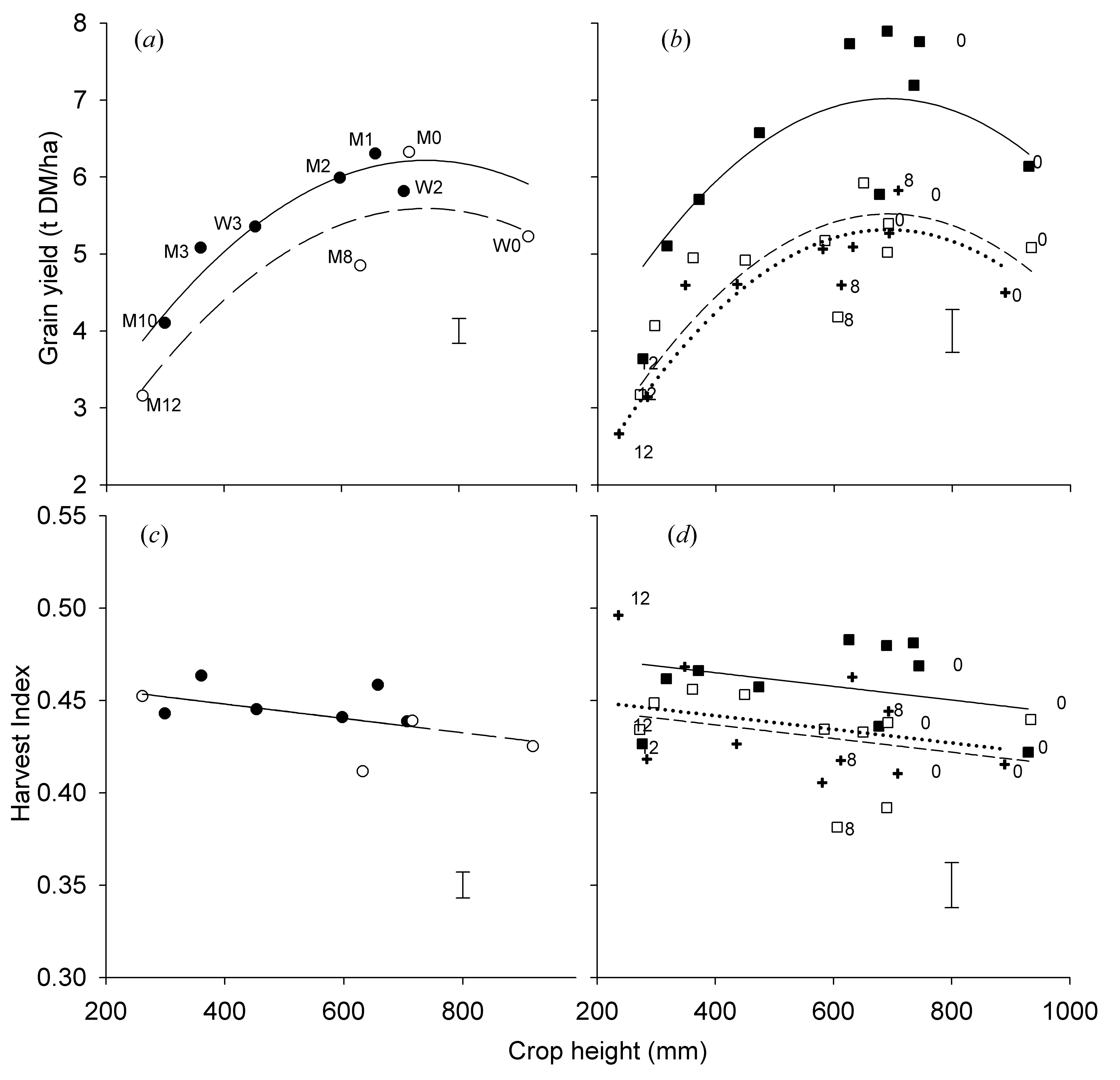




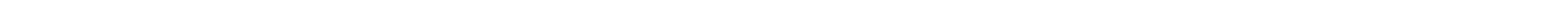




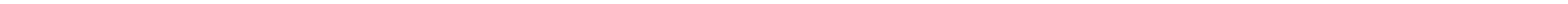

